\title{
STEREOTIPI I OSJEĆAJI KAO PREDIKTORI NAMJERA PONAŠANJA U KONTEKSTU IZBJEGLIČKE KRIZE
}

\author{
Renata Franc \\ Institut društvenih znanosti Ivo Pilar \\ Marulićev trg 19/I, 10000 Zagreb \\ renata.franc@pilar.hr \\ Marina Maglić \\ Institut društvenih znanosti Ivo Pilar \\ Marulićev trg 19/I, 10000 Zagreb \\ marina.maglic@pilar.hr \\ Tomislav Pavlović* \\ Institut društvenih znanosti Ivo Pilar \\ Marulićev trg 19/I, 10000 Zagreb \\ tomislav.pavlovic@pilar.hr
}

\begin{abstract}
Sažetak
Cilj rada je u kontekstu izbjegličke krize provjeriti ulogu stereotipa i međugrupnih emocija u objašnjenju iskazanih namjera međugrupnih ponašanja polazeći od proširenog Modela sadržaja stereotipa, tzv. BIAS map modela. Rad temeljimo na podacima prikupljenim 2016. godine online anketiranjem prigodnog uzorka hrvatskih građana $(N=468)$ na temu stavova o izbjeglicama. Korištenim instrumentima zahvatili smo dvije dimenzije osobnih stereotipa o izbjeglicama: toplinu i kompetentnost, četiri međugrupne emocije: divljenje, zavist, prezir i sažaljenje, te namjere dvaju tipova ponašanja: aktivno pomaganje i aktivno nanošenje štete izbjeglicama. Na općoj razini rezultati upućuju na to da stereotipi i međugrupne emocije predviđaju namjere aktivnog pomaganja i aktivnog nanošenja štete izbjeglicama. Konkretno, u skladu s postavkama BIAS modela potvrđeno je da su stereotipi o toplini (u odnosu na stereotipe o kompetentnosti) primarni prediktori namjera i aktivnog pomaganja i nanošenja štete, a da su emocije bitni neposredni prediktori namjera te da (djelomično) posreduju efekte stereotipa na namjere aktivnih ponašanja. Međutim, rezultati o pojedinim
\end{abstract}

* Tomislav Pavlović zaposlen je na projektu DARE (EU Obzor 2020, 725349) preko natječaja "Projekt razvoja karijera mladih istraživača - izobrazba novih doktora znanosti” (DOK-01-2018) Hrvatske zaklade za znanost uz potporu Europskog socijalnog fonda (ESF). 
emocijama kao prediktorima aktivnih ponašanja i posrednicama efekata stereotipa, sukladno dijelu dosadašnjih nalaza, odstupaju od teorijskih očekivanja.

Ključne riječi: stereotipi, međugrupne emocije, namjere ponašanja, međugrupni odnosi, izbjeglice

\section{UVOD}

Mogućnost predviđanja ponašanja na temelju stavova jedno je od ključnih i trajnih pitanja u socijalnoj psihologiji. Pritom, suštinsko je pitanje „Kakvi stavovi, kod kojih pojedinaca, u kojim uvjetima omogućuju predviđanje kakvog ponašanja"? (Fazio i Zanna, 1981, str. 165). Time se ističe važnost i strukture stavova i razlikovanja tipova ponašanja koji se njima nastoje objasniti. Kad je riječ o međugrupnim ponašanjima, recentni pristupi kao osnovne odrednice ponašanja ističu stereotipe i osjećaje te jasno specificiranju njihov odnos s različitim oblicima ponašanja (Cuddy, Fiske i Glick, 2007, 2008; Fiske, Cuddy i Glick, 2007; Fiske, Cuddy, Glick i $\mathrm{Xu}, 2002)$.

Prema Modelu sadržaja stereotipa (MSS, Fiske i sur., 2007; Fiske i sur., 2002) toplina i kompetentnost temeljne su dimenzije socijalne percepcije općenito, pa tako i percepcije grupa. Naime, procjenjivanjem topline i kompetentnosti odgovaramo na dva ključna pitanja: a) kakve su namjere drugog pojedinca ili grupe - dobre ili loše (procjene na dimenziji topline) te b) koliko je druga osoba ili grupa sposobna, vješta i učinkovita u ostvarenju svojih ciljeva (procjene kompetentnosti) (Cuddy i sur., 2008; Fiske i sur., 2007, 2002). Valjanost ovakve dvodimenzionalne strukture sadržaja stereotipa potvrđena je u različitim kulturalnim kontekstima (Binggeli, Krings i Sczesny, 2014; Bye, Herrebrøden, Hjetland, Røyset i Westby, 2014; Cuddy i sur., 2008; Krajina, 2009; Kuljiš, 2009; Pahić, 2006) iako dio istraživanja upućuje na to da procjene moralnosti čine treću zasebnu dimenziju stereotipa (Brambilla $\mathrm{i}$ Leach, 2014; Leach, Ellemers i Barreto, 2007). Nadalje, MSS specificira koja je od četiri pretpostavljene osnovne međugrupne emocije (zavist, prezir, divljenje, sažaljenje) dominantna uz pojedine kombinacije stereotipa. Primjerice, ako se grupa opaža i toplom i kompetentnom (uobičajeno za procjene vlastite grupe), pretpostavljena dominantna emocija je divljenje. Ako su pak stereotipi o vanjskoj grupi na obje dimenzije negativni, očekuje se izraženi prezir. U slučaju ambivalentnih stereotipa, ako se grupa percipira kompetentnom, ali hladnom, dominantna očekivana emocija je zavist, dok se, ako se grupa vrednuje pozitivno u pogledu topline, ali nije percipirana kompetentnom, kao dominanta emocija očekuje sažaljenje (Fiske, 2015; Fiske i sur., 2002).

1 Treba spomenuti da dio autora (npr. Phalet i Poppe, 1997; Wojciszke, 1997) upotrebljava naziv moralnost za opću dimenziju stereotipa o društvenim aspektima, dakle, prema Modelu sadržaja stereotipa (Fiske i sur., 2002), dimenziju topline koja obuhvaća i karakteristike moralnosti. 
Proširenjem MSS-a tzv. BIAS modelom (Behaviors from Intergroup Affect and Stereotypes Map - BIAS map, Cuddy i sur., 2007, 2008) razlikuju se i četiri tipa međugrupnih ponašanja: aktivna ponašanja $u$ korist vanjske grupe (npr. aktivno pomaganje, pomoć ili obrana), aktivna ponašanja usmjerena protiv vanjske grupe (suprotstavljanje i nanošenje štete, npr. tjelesni ili verbalni napadi), pasivna ponašanja u korist grupe (ponašanja slabijeg intenziteta koja ne uključuju izravno pomaganje, već više toleriranje grupe) te pasivna ponašanja na štetu vanjske grupe (ignoriranje ili zanemarivanje vanjske grupe bez aktivnog nanošenja štete).

Konačno, BIAS modelom specificira se uloga svake pojedine dimenzije stereotipa i emocija u objašnjenju četiri tipa ponašanja (Cuddy i sur., 2007). Tako se očekuje da smjer aktivnih ponašanja ponajprije ovisi o smjeru procjena topline (pozitivni stereotipi - pomaganje i zaštita, negativni stereotipi - napadi i borba), a smjer pasivnih ponašanja o smjeru procjena kompetentnosti (pozitivni stereotipi povezivanje i suradnja, negativni stereotipi - zanemarivanje i ignoriranje). Što se tiče emocija kao odrednica ponašanja, za razumijevanje ponašanja u korist grupe očekuje se važnost divljenja, te dodatno sažaljenja (kod aktivnog pomaganja) ili zavisti (kod pasivnog pomaganja). Kada se pak radi o ponašanjima protiv grupe očekuje se važnost prezira, te dodatno zavisti (kod aktivnog nanošenje štete) ili sažaljenja (kod pasivnog nanošenja štete) (Cuddy i sur., 2007). Dodatno, za emocije se očekuje i da posreduju efekte stereotipa na ponašanja (Cuddy i sur., 2007): divljenje posreduje efekte stereotipa o toplini na aktivno pomaganje i stereotipa o kompetentnosti na pasivno pomaganje, prezir posreduje efekte stereotipa o toplini na aktivno nanošenje štete i stereotipa o kompetentnosti na pasivno nanošenje štete, zavist posreduje efekte stereotipa o toplini na aktivno nanošenje štete i stereotipa o kompetentnosti na pasivno pomaganje, dok sažaljenje posreduje efekte stereotipa o toplini na aktivno pomaganje i stereotipa o kompetentnosti na pasivno nanošenje štete.

Dosadašnje provjere na općoj razini dosljedno potvrđuju stereotipe i emocije kao prediktore međugrupnih ponašanja, kao i medijacijsku ulogu emocija, iako su nalazi o ulozi pojedinih dimenzija stereotipa i pojedinih emocija često nedosljedni (Becker i Asbrock, 2012; Bye i Herrebrøden, 2018; Constantin i Cuadrado, 2020; Cuddy i sur., 2007; Sadler, Kaye i Vaughn, 2015; Ufkes, Otten, van der Zee, Giebels i Dovidio, 2012; Vaughn, Teeters, Sadler i Cronan, 2017). Primjerice, i sami autori modela Cuddy i sur. (2007) nisu potvrdili posredovanje zavisti u odnosu stereotipa o toplini i aktivnog nanošenja štete, niti posredovanje prezira u odnosu stereotipa o kompetenciji i pasivnog nanošenja štete. Bye i Herrebrøden (2018), analizirajući dosljednost nalaza o pojedinim emocijama kao posrednicima efekata stereotipa na ponašanja, upućuju i na različitost dizajna i korištenih operacionalizacija kao moguće razloge nedosljednih nalaza, uz naglašavanje potrebe dodatnih provjera BIAS modela.

Cilj je ovog istraživanja, polazeći od BIAS modela, provjeriti uloge osobnih stereotipa i emocija u objašnjenju iskazanih namjera ponašanja. Istraživanje se 
temelji na podacima o osobnim stereotipima i međugrupnim emocijama te namjerama ponašanja prigodnog online uzorka hrvatskih građana prema realnoj, i posljednjih godina, relevantnoj društvenoj grupi - izbjeglicama. Naime, iako se Europa posljednjih godina suočava s izazovima migracijske i izbjegličke krize, broj istraživanja u kojima su testirane postavke MSS i BIAS modela nije velik. Ono što rezultati tih istraživanja pokazuju jest da različite grupe imigranata u SAD-u i Europi uglavnom procjenjivane nisko na dimenziji topline i kompetentnosti (Asbrock, 2010; Binggeli i sur., 2014; Eckes, 2002; Kotzur, Friehs, Asbrock i van Zalk, 2019; Lee i Fiske, 2006). Ujedno, u Hrvatskoj je dosada veći broj istraživanja vezan uz izbjeglice i izbjegličku krizu, međutim nema istraživanja koja su eksplicite provjeravala MSS ili BIAS model (izuzev rijetkih diplomskih radova). U kontekstu stavova prema izbjeglicama dosadašnja istraživanja u Hrvatskoj uglavnom se bave zastupljenošću općih stavova ili pojedinih dimenzija stavova prema izbjeglicama ili azilantima (CMS, 2017), odnosno mogućnošću objašnjenja ovih stavova na temelju različitih odrednica kao što su ličnost, ideološke orijentacije, percipirana prijetnja (Ajduković, Čorkalo Biruški, Gregurović, Matić Bojić i Župarić-Iljić, 2019; Matić, Löw i Bratko, 2018), pri čemu se samo u jednom nastojalo objasniti i namjere ponašanja (Ajduković i sur., 2019).

Podatke smo prikupili tijekom druge polovice 2016. godine, nakon vrhunca suočavanja Hrvatske s ,izbjegličkom krizom“ koja je započela u drugoj polovici 2015. godine priljevom brojnih izbjeglica ponajprije iz Sirije, Afganistana i Iraka na njihovu putu u zapadnoeuropske zemlje (Šabić i Borić, 2016). Od četiri tipa ponašanja koja se razlikuju BIAS modelom, uloge stereotipa i emocija provjerili smo u odnosu na dva: namjeru aktivnog pomaganja te namjeru aktivnog nanošenja štete, dok namjere pasivnih ponašanja nismo obuhvatili. Ujedno, početna provjera dimenzionalnosti korištenih mjera stereotipa i emocija potvrdila je opravdanost formiranja rezultata za dvije dimenzije stereotipa (toplina i kompetentnost) te sve četiri međugrupne emocije.

U radu smo testirali sljedeće hipoteze:

1) da će stereotipi o toplini izbjeglica biti važniji prediktori obaju namjera aktivnih ponašanja u odnosu na stereotipe o kompetentnosti

2) da će emocije divljenja i sažaljenja biti relativno važniji prediktori namjere aktivnog pomaganja nego emocije prezira i zavisti

3) da će emocije prezira i zavisti biti relativno važniji prediktori namjera aktivnog nanošenja štete nego emocije divljenja i sažaljenja

4) da će emocije divljenja i sažaljenja biti posrednice efekata stereotipa o toplini na namjeru aktivnog pomaganja

5) da će emocije prezira i zavisti biti posrednice efekata stereotipa na namjeru aktivnog nanošenja štete. 


\section{METODA}

\section{Sudionici i postupak}

Korištene podatke prikupili smo opsežnijom online anonimnom anketom ${ }^{2}(\mathrm{u}$ razdoblju od 22. listopada do 17. studenog 2016.) uz odobrenje Etičkog povjerenstva Instituta društvenih znanosti Ivo Pilar. Prije početka ispunjavanja ankete sudionike smo uputom obavijestili o svrsi istraživanja, da se radi o dobrovoljnom i anonimnom istraživanju te da u svakom trenutku mogu odustati od sudjelovanja.

Od kontaktiranih 1100 članova online panela jedne privatne tvrtke, 484 sudionika (44\%) je odgovorilo na sva relevantna pitanja te smo njihove rezultate upotrebljavali u daljnjim analizama. Prosječna dob sudionika je 34,82 godine $(S D=$ 11,40 ), većinom se radi o ženama ( $63 \%$ ), zaposlenim osobama ( $58 \%$ zaposleni, $17 \%$ nezaposleni, $15 \%$ studenti, $5 \%$ umirovljenici, $5 \%$ ostalo) te osobama sa završenom srednjom školom (51\%; 26\% diplomski studij, magisterij, doktorat; $20 \%$ preddiplomski ili stručni studij; $2 \%$ osnovna škola).

\section{Instrumenti ${ }^{3}$}

\section{Osobni stereotipi}

Stereotipe smo mjerili s 11 pridjeva $^{4}$, uz pitanje „Koliko svaka od sljedećih osobina dobro opisuje izbjeglice koje trenutačno dolaze u Europu?" i ponuđene odgovore od 1 - uopće ne opisuje do 7 -jako dobro opisuje. Za svaku od tri moguće dimenzije stereotipa upotrebljavali smo najmanje po tri pridjeva (kompetentnost: inteligentni, vješti, neobrazovani; toplina: prijateljski, simpatični, topli, grubi; moralnost: pošteni, iskreni, pouzdani, lažljivi). Slaganje trofaktorskog modela koreliranih faktora s podacima nije se pokazalo primjerenim $\left(\chi^{2} / \mathrm{df}=16,54\right.$, robusni $\mathrm{CFI}=, 96$, robusni $\mathrm{RMSEA}=, 18$, SRMR $=, 11)$, što je bilo razvidno i iz gotovo singularnih dimenzija procjena moralnosti i topline $(r=, 98)$. Model pojednostavljen spajanjem dimenzija topline i moralnosti također nije rezultirao primjerenim slaganjem $\left(\chi^{2} / \mathrm{df}=16,33\right.$, robusni $\mathrm{CFI}=, 86$, robusni RMSEA $\left.=, 18, \mathrm{SRMR}=, 11\right)$. Primjereno slaganje postignuto je tek nakon izbacivanja negativnih osobina lažljivi

2 Podaci su prikupljeni u okviru međunarodnog anketiranja pod nazivom Stavovi o izbjeglicama provedenom u više europskih zemalja unutar COST Akcije IS1205 „Social Psychological dynamics of historical representations in the enlarged European Union“" uz originalna pitanja na engleskom koja su prevedena na hrvatski

3 Opisani su samo instrumenti kojima su prikupljeni podaci korišteni u ovom radu.

4 U originalnoj verziji na engleskom jeziku ljestvica stereotipa sadrži 12 pridjeva, no pridjev „kompetentni“ propustom je izostavljen u hrvatskoj verziji. 
i grubi iz modela s dvama koreliranim faktorima $\left(\chi^{2} / \mathrm{df}=1,94\right.$, robusni $\mathrm{CFI}=, 99$, robusni $\mathrm{RMSEA}=, 06, \mathrm{SRMR}=, 02)($ Slika 1$)$.

\section{Međugrupne emocije}

Međugrupne emocije mjerili smo pitanjem „Kada mislite na izbjeglice koji trenutačno dolaze u Europu, u kojoj mjeri osjećate..." s ponuđenih 11 emocija (prezir, divljenje, sažaljenje, mržnju, gađenje, simpatiju, zavist, ljutnju, ponos, suosjećanje i ljubomoru) i ponuđenim odgovorima od 1- uopće ne do 7 - vrlo jako (Fiske i sur., 2002). Strukturu početnog modela s četirima koreliranim dimenzijama emocija nismo potvrdili $\left(\chi^{2} / \mathrm{df}=4,49\right.$, robusni CFI $=, 92$, robusni $\mathrm{RMSEA}=, 11$, SRMR $=, 08)$ zbog visokih povezanosti čestice simpatije s ostalim emocijama. No, nakon uklanjanja ove čestice model se pokazao primjeren podacima $\left(\chi^{2} / \mathrm{df}=2,75\right.$, robusni $\mathrm{CFI}=, 97$, robusni $\mathrm{RMSEA}=, 06, \mathrm{SRMR}=, 05)($ Slika 2$)$.

\section{Namjere aktivnih ponašanja}

Namjere ponašanja mjerili smo sa šest čestica koje opisuju aktivna ponašanja - tri čestice ponašanja u korist izbjeglica (sudjelovati u demonstracijama za prava izbjeglica, pridružiti se i sudjelovati u radu udruge koja pomaže izbjeglicama, za izbjeglice donirati pokrivače, odjeću i sl.), a tri protiv izbjeglica (potpisati peticiju kojom se ograničava broj izbjeglica koje će Hrvatska primiti, sudjelovati u demonstracijama protiv izbjeglica, podržati političke odluke/mjere s ciljem protjerivanja izbjeglica iz Europe) uz ponuđene odgovore od 1 - uopće ne bih bio/bila spreman/a do 7 - jako bih bio/la spreman/a. Korištene čestice namjera ponašanja formulirane su na temelju adaptacije Skale kolektivnog djelovanja autora van Zomerena, Postmesa i Spearsa (2008). Slaganje dvofaktorskog modela s koreliranim faktorima s podacima pokazalo se marginalno prihvatljivim $\left(\chi^{2} / \mathrm{df}=12,13\right.$, robusni $\mathrm{CFI}=, 93$, robusni $\mathrm{RMSEA}=, 16, \mathrm{SRMR}=, 07)^{5}$.

\section{REZULTATI}

Radi odgovora na osnovni cilj rada i provjere hipoteza podatke smo obradili strukturalnim modeliranjem ${ }^{6}$ u programu $R$ (v.3.5.3). Kako bismo utvrdili prosječne

5 Iako je navedeno slaganje s podacima tek marginalno prihvatljivo, bolje je u odnosu na slaganje jednofaktorskog modela $\left(\chi^{2} / \mathrm{df}=28,01\right.$, robusni $\mathrm{CFI}=, 76$, robusni RMSEA $=$ ,28, SRMR $=, 10)$ i jednofaktorskog modela kojem su dodane tri korelacije reziduala $\left(\chi^{2} / \mathrm{df}=15,23\right.$, robusni CFI $=, 93$, robusni $\left.\mathrm{RMSEA}=, 18, \mathrm{SRMR}=, 06\right)$, pri čemu potonji rezultat predstavlja ishod trećeg kruga modifikacija. Stoga je, sukladno pokazateljima slaganja i cilju istraživanja u vezi s predviđanjem namjera i pozitivnih i negativnih ponašanja, zadržano dvofaktorsko rješenje.

6 Svi strukturalni modeli izračunati su uz Brosseau-Liard i Savalei (2014) korekciju za odstupanja od normalnosti raspodjela. 


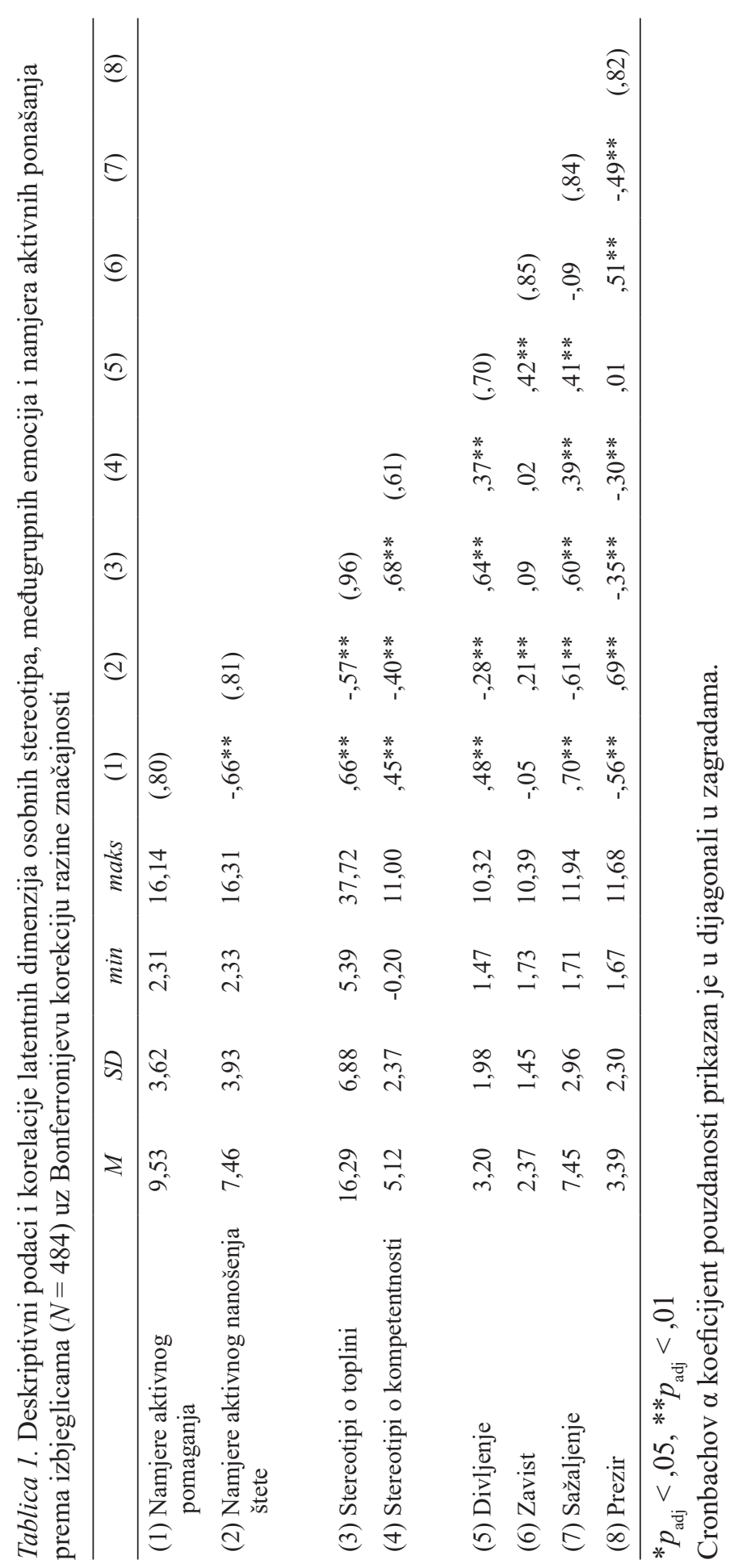

(C) "Naklada Slap", 2019. Sva prava pridržana. 
rezultate, najprije smo formirali strukturalni model sa svim latentnim konstruktima koji se pokazao primjerenim $\left(\chi^{2} / \mathrm{df}=2,63\right.$, robusni $\mathrm{CFI}=, 94$, robusni RMSEA $=$ $, 06, \mathrm{SRMR}=, 07)$. Rezultate latentnih varijabli ${ }^{7}$ izračunali smo na temelju saturacija odgovarajućih čestica iz modela, a korelacije na temelju ekstrakcije korelacija latentnih varijabli ${ }^{8}$ (Tablica 1). U Prilogu su prikazane i funkcije distribucija dimenzija stereotipa, emocija i namjera aktivnih ponašanja prema izbjeglicama.

Sudionici su izbjeglice procijenili osrednje kompetentnima, te još manje toplima. Ujedno, sudionici su prema izbjeglicama u prosjeku naveli srednje jake osjećaje sažaljenja, slabe osjećaje prezira i divljenja dok zavist nisu osjećali (Tablica 1 i Prilog). S obzirom na relativno niske procjene stereotipa na obje dimenzije, pogotovo na dimenziji topline, sukladno MSS-u i dosadašnjim nalazima, kao relativno najizraženija emocija prije bi se očekivala emocija prezira nego sažaljenja (Fiske, 2015). Prosječne vrijednosti namjera pokazuju da sudionici u prosjeku nisu ni spremni niti nespremni na aktivna ponašanja, slično nedavnim nalazima o namjerama ponašanja hrvatskih građana prema azilantima (Ajduković, i sur., 2019).

Povezanosti relevantne za provjeru hipoteza sukladne su očekivanjima, iako su nešto više od do sada utvrđenih, vjerojatno stoga što smo upotrebljavali latentne, a ne manifestne varijable (Bye i Herrebrøden, 2018; Cuddy i sur., 2007). Obje namjere aktivnih ponašanja u višim su korelacijama sa stereotipima o toplini nego s onima o kompetentnosti (koje karakterizira i nešto niža pouzdanost). Namjera aktivnog pomaganja izbjeglicama, sukladno pretpostavkama, u značajnoj je pozitivnoj vezi sa sažaljenjem i divljenjem te u značajnoj negativnoj, relativno visokoj korelaciji s prezirom te nije povezana sa zavišću. Značajne pozitivne korelacije namjere aktivnog nanošenja štete izbjeglicama, sukladno očekivanjima, utvrđene su s prezirom te sa zavišću. Pritom su utvrđene i statistički značajne negativne korelacije s ostalim dvjema emocijama - relativno visoka sa sažaljenjem te niža s divljenjem. Ujedno, sve očekivane korelacije između stereotipa i emocija su statistički značajne, osim sa zavišću, pri čemu su općenito emocije u višim korelacijama sa stereotipima o toplini nego stereotipima o kompetentnosti (Tablica 1).

\section{Stereotipi kao prediktori namjera aktivnih ponašanja}

Početni model sa stereotipima o toplini i kompetentnosti kao prediktorima obaju namjera (Slika 1) pokazao se primjeren podacima $\left(\chi^{2} / \mathrm{df}=2,81\right.$, robusni $\mathrm{CFI}=, 95$, robusni $\mathrm{RMSEA}=, 07, \mathrm{SRMR}=, 06$ ).

7 Takav je postupak odabran jer lavaan (Rosseel, 2012) po definiciji ograničava prosjek latentnih varijabli na 0 , dok postupci dokidanja navedenog ograničenja također ne omogućavaju prikaz punog raspona ljestvice.

8 Korištena je funkcija lavInspect() iz lavaan (Rosseel, 2012). 


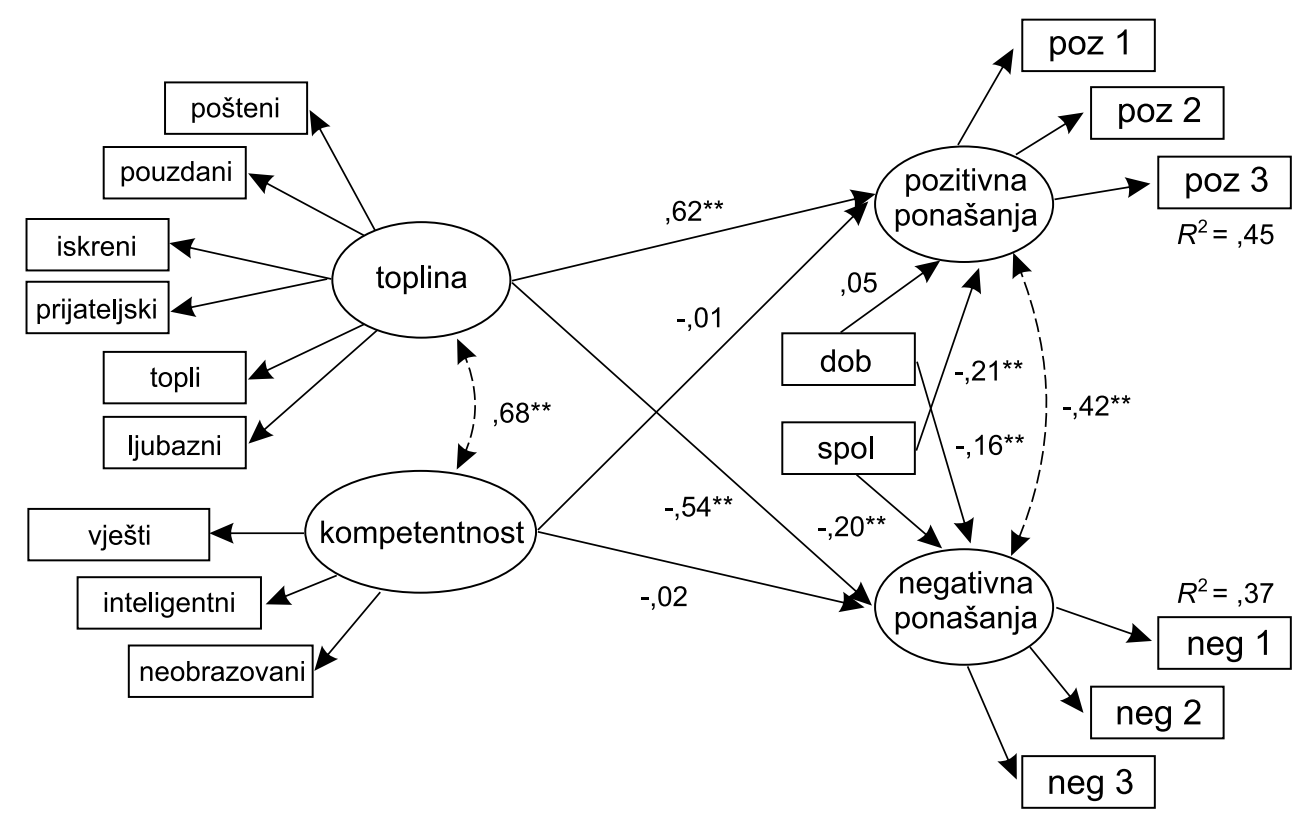

Slika 1. Stereotipi topline i kompetentnosti kao prediktori namjera aktivnih ponašanja prema izbjeglicama $(N=484, * p<, 01, * * p<, 001)$.

Ostvareno je relativno dobro objašnjenje varijance namjera aktivnog pomaganja $\left(R^{2}=, 45\right)$, te nešto slabije objašnjenje namjere aktivnog nanošenja štete izbjeglicama $\left(R^{2}=, 37\right)$. Ostvarenom objašnjenju obje namjere statistički značajno doprinose samo stereotipi o toplini $\left(\beta_{\text {pomaganje }}=, 62, p<, 001, \beta_{\text {nanošenje stete }}=-, 54, p<, 001\right)$, dok stereotipi o kompetentnosti nemaju samostalnog doprinosa $\left(\beta_{\text {pomaganje }}=-, 01, p>, 05\right.$, $\left.\beta_{\text {nanošenje štete }}=-, 02, p>, 05\right)$. Pritom je utvrđen i značajan doprinos spola objašnjenju namjera aktivnih ponašanja - muškarci su se pokazali sklonijima negativnim $(\beta=$ $, 20, p<, 001)$, a žene $(\beta=-, 21, p<, 001)$ i stariji sudionici $(\beta=-, 16, p<, 001)$ pozitivnim aktivnim ponašanjima.

\section{Stereotipi i emocije kao prediktori namjera ponašanja}

Model sa stereotipima i emocijama kao prediktorima namjera ponašanja te ujedno emocijama kao medijatorima odnosa stereotipa i namjera, uz kontrolu efekata dobi i spola (Slika 2) pokazao se primjeren podacima $\left(\chi^{2} / \mathrm{df}=2,63\right.$, robusni $\mathrm{CFI}=$ ,94, robusni $\mathrm{RMSEA}=, 06, \mathrm{SRMR}=, 07$ ). 


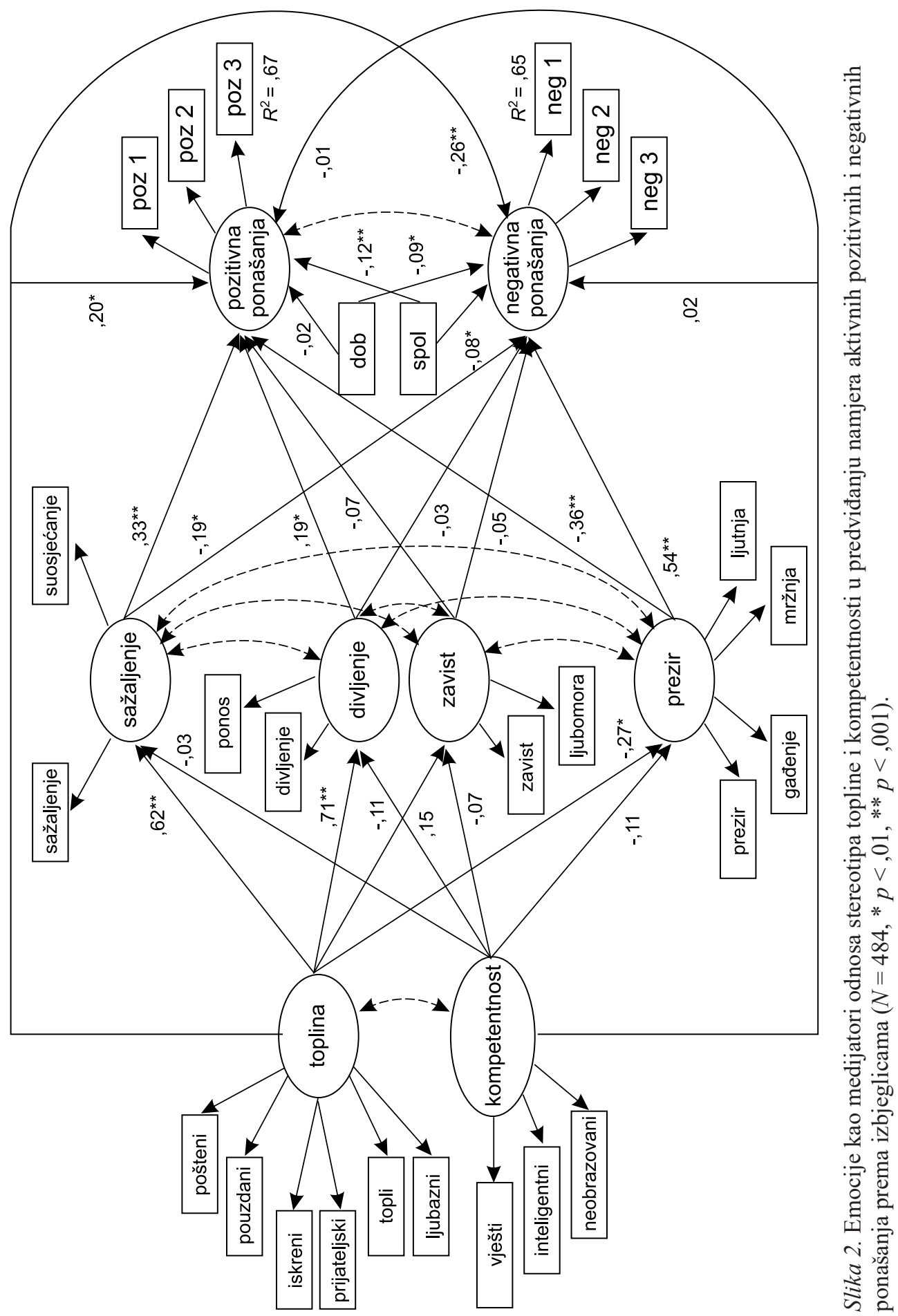


Ostvarenom objašnjenju namjere aktivnog pomaganja (67\%), sukladno očekivanjima, od emocija samostalno pridonose sažaljenje $(\beta=, 33, p<, 001)$ i divljenje $(\beta=, 19, p<, 01)$, dok značajan doprinos zavisti nije utvrđen $(\beta=-, 07, p>, 05)$. Suprotno očekivanju, utvrđen je i statistički značajan (i relativno velik) doprinos odsutnosti prezira $(\beta=-, 36, p<, 001)$. Stereotipi o toplini, uz efekte posredovane emocijama (indirektni: $\beta_{\text {prezir }}=, 20, p<, 001, \beta_{\text {sažalijenje }}=, 10, p=, 002, \beta_{\text {divljenje }}=, 13$, $p=, 003)$ imaju i izravan samostalan doprinos $(\beta=, 20, p<, 01)$, dok stereotipi o kompetentnosti nemaju samostalan doprinos $(\beta=-, 01, p>, 05)$.

Ostvarenom objašnjenju namjere aktivnog nanošenja štete (65\%), sukladno očekivanju, samostalno pridonosi prezir $(\beta=, 54, p<, 001)$ i, neočekivano, odsutnost sažaljenja $(\beta=-, 19, p<, 01)$. S druge strane, nije potvrđen pretpostavljeni doprinos zavisti $(\beta=-, 05, p>, 05)$, a sukladno očekivanju nije utvrđen doprinos divljenja ( $\beta=-, 03, p>, 05)$. I u ovom slučaju, stereotipi o toplini, uz efekte posredovane prezirom i sažaljenjem (indirektni: $\beta_{\text {prezir }}=-, 12, p=, 003 ; \beta_{\text {sažaljenje }}=-, 15, p$ $=, 001)$, imaju i izravan, ali negativan doprinos $(\beta=-, 26, p<, 01)$, dok stereotipi o kompetentnosti nemaju izravan doprinos $(\beta=, 02, p>, 05)$.

Povezanost dobi i spola s namjerama ponašanja u ovom modelu replicirao je rezultate prethodnog, iako u nešto slabijem intenzitetu: muškarci su i dalje bili skloniji od žena negativnim $(\beta=, 08, p<, 01)$, a manje skloni pozitivnim ponašanjima ( $\beta=$ $-, 12, p<, 001)$, kao i mlađi sudionici $(\beta=-, 09, p<, 01)$.

\section{RASPRAVA}

$\mathrm{Na}$ općoj razini istraživanje pokazuje da stereotipi o toplini i međugrupne emocije omogućuju dobro objašnjenje namjera aktivnog pomaganja i aktivnog nanošenja štete izbjeglicama. Tako je aktivno pomaganje izbjeglicama vjerojatnije kada ih procjenjujemo toplijima, te prema njima osjećamo sažaljenje i divljenje, uz odsutnost prezira. Za razliku od toga, aktivno odmaganje izbjeglicama vjerojatnije je kada ih procjenjujemo negativnije u pogledu topline te prema njima osjećamo prezir, uz odsutnost sažaljenja. Rezultati potvrđuju prvu hipotezu o primarnosti stereotipa o toplini u odnosu na stereotipe o kompetenciji pri objašnjavanju namjera aktivnih međugrupnih ponašanja te upućuju na to da je za razumijevanje $\mathrm{i}$ aktivnog pomaganja i aktivnog nanošenja štete izbjeglicama važno koliko izbjeglice procjenjujemo toplima ili hladnima, a ne koliko ih procjenjujemo kompetentnima. Ovi su nalazi sukladni BIAS modelu i nalazima o lakšoj kognitivnoj pobudljivosti procjena društvenih aspekata pojedinaca ili grupa, odnosno većom važnosti percipiranih dobrih ili loših namjera vanjske grupe nego njihove kompetentnosti za ostvarivanje tih namjera (Cuddy i sur., 2008; Fiske, 2015; López-Rodríguez i Zagefka, 2015). S obzirom na to da stereotipi topline ovise o percipiranoj prijetnji, rezultati su sukladni i nalazima koji upućuju na to da su percipirane prijetnje važni prediktori ponašanja prema vanjskim grupama općenito te imigrantima posebice 
(Ajduković i sur., 2019; Bye i sur., 2014; Franc, Šakić i Kaliterna-Lipovčan, 2010; Gregurović, Kuti i Župarić-Iljić, 2016; Kervyn, Fiske i Yzerbyt, 2015; Pereira, Vala i Costa-Lopes, 2010). Kad je riječ o stereotipima o toplini, vrijedi napomenuti i da rezultati ovog istraživanja ne govore u prilog razlikovanju stereotipa topline od stereotipa moralnosti, te su i u tom smislu sukladni MSS-u, prema kojem su kulturalni stereotipi o moralnosti dio šire shvaćene dimenzije topline (Fiske, 2015).

Istraživanjem smo na općoj razini potvrdili i međugrupne emocije kao neposredne prediktore namjera obaju aktivnih ponašanja. Pritom su i druga i treća hipoteza potvrđene samo djelomično. Prema drugoj hipotezi, očekivali smo da će emocije divljenja i sažaljenja biti relativno važniji prediktori namjere aktivnog pomaganja nego emocije prezira i zavisti. Iako su sažaljenje i divljenje potvrđene kao samostalni prediktori namjera aktivnog pomaganja, rezultati su suprotno očekivanju pokazali da objašnjenju aktivnog pomaganja samostalno (i relativno najviše) pridonosi i odsutnost negativne emocije prezira. Samostalna prediktivnost odsutnosti prezira u objašnjenju namjera aktivnog pomaganja, osim što nije sukladna očekivanjima, predstavlja i novi nalaz u kontekstu provjera BIAS modela. Tome je moglo pridonijeti i to što smo, za razliku od većine dosadašnjih istraživanja koja provjeravaju efekte po parovima pretpostavljenih dominantnih emocija, istovremeno provjeravali efekte svih četiriju međugrupnih emocija (Bye i Herrebrøden, 2018; Sadler i sur., 2015; Vaughn i sur., 2017). Trećom smo hipotezom očekivali da će prezir i zavist biti relativno važniji prediktori namjera aktivnog nanošenja štete izbjeglicama nego divljenje i sažaljenje. Iako je pri objašnjenju namjera aktivnog nanošenja štete potvrđena važnost prezira kao neposrednog i relativno najvažnijeg emocionalnog prediktora, nije utvrđen očekivani doprinos zavisti, dok je utvrđena važnost odsutnosti sažaljenja. Moguće objašnjenje za neutvrđivanje efekta zavisti na namjeru aktivnog nanošenja štete jest da zavist određuje aktivno nanošenje štete samo pri izraženom međugrupnom neprijateljstvu (Cuddy i sur., 2007). K tome, čestice kojima smo mjerili namjeru nanošenja štete opisuju aktivna ponašanja kojima se izbjeglicama šteta nanosi više neizravno (potpisivanje peticije, sudjelovanje u demonstracijama, podrška političkim odlukama) u odnosu na izravne neprijateljske postupke poput tjelesnih ili verbalnih napada. Stoga je pitanje koliko dobro korišteni rezultat namjere nanošenja štete operacionalizira baš aktivno nanošenje štete, a koliko ponašanja koja su negdje između aktivnih i pasivnih. Ova se interpretacija može primijeniti i na utvrđenu važnost odsutnosti sažaljenja, budući da je sažaljenje, uz prezir, očekivan prediktor pasivnog nanošenja štete. S druge strane, ako te čestice doista mjere više pasivno nego aktivno negativno ponašanje, rezultati ne potvrđuju očekivani efekt stereotipa kompetentnosti kao prediktora pasivnog nanošenja štete, te bi utvrđene nalaze svakako trebalo provjeriti sveobuhvatnijom i preciznijom mjerom svih četiriju tipova ponašanja.

Istraživanjem smo na općoj razini potvrdili i međugrupne emocije kao posrednice efekata stereotipa topline na namjere obaju tipova aktivnih ponašanja. Međutim, i u ovom smo slučaju samo djelomično potvrdili četvrtu i petu hipotezu. Naime, suk- 
ladno četvrtoj hipotezi i divljenje i sažaljenje potvrđeni su kao posrednici efekata stereotipa topline iako većina dosadašnjih istraživanja potvrđuje samostalnu medijacijsku ulogu samo jedne od ovih dviju emocija (Becker i Asbrock, 2012; Bye i Herrebrøden, 2018; Sadler i sur., 2015). Međutim, suprotno četvrtoj hipotezi prezir se također pokazao kao važan posrednik efekata stereotipa o toplini na aktivna pomaganja.

U pogledu posredovanja efekata stereotipa o toplini na namjere aktivnog nanošenja štete očekivali smo važnost prezira i zavisti. Sukladno petoj hipotezi, prezir je potvrđen kao posrednik efekata stereotipa topline u objašnjenju namjere aktivnog nanošenja štete, međutim nije potvrđena očekivana uloga zavisti, pri čemu su oba nalaza sukladna dosadašnjima (Becker i Asbrock, 2012; Bye i Herrebrøden, 2018; Cuddy i sur., 2007; Sadler i sur., 2015). Suprotno očekivanjima, rezultati upućuju i na posredujuću ulogu sažaljenja pri objašnjenju namjera aktivnog nanošenja štete. I u ovom slučaju može se raditi o novom nalazu koji odstupa od očekivanja, koji možda proizlazi iz navedene nedovoljno precizne operacionalizacije namjere nanošenja štete (koja više predstavlja kombinaciju aktivnog i pasivnog, nego čisto aktivnog nanošenja štete).

Općenito, u pogledu uloge emocija rezultati pokazuju da su prezir i sažaljenje relativno najvažniji i samostalni prediktori i posrednici efekata stereotipa topline na obje namjere ponašanja, iako se to očekuje za prezir i divljenje (Cuddy i sur., 2007; Vaughn i sur., 2017). Dodatni nalaz ovog istraživanja je da emocije samo djelomično posreduju efekte stereotipa o toplini na aktivna ponašanja. Naime, prema utvrđenim rezultatima, stereotipi o toplini, uz očekivani neizravan efekt na obje namjere aktivnih ponašanja posredovan emocijama, imaju i izravan efekt koji se ne može objasniti emocijama kao medijatorima. Mogući razlog za ova odstupanja je i to što postavke MSS-a i BIAS-a ponajprije vrijede za situacije izraženih stereotipa i emocija, što nije slučaj u ovom istraživanju.

Pri ocjeni nalaza ovog istraživanja treba istaknuti i dodatne bitne razlike u odnosu na većinu dosadašnjih istraživanja (Bye i Herrebrøden, 2018). Naime, ovo je istraživanje (kao i manji broj dosadašnjih, npr. Becker i Asbrock, 2012; Constantin i Cuadrado, 2020; Ufkes i sur., 2012) usmjereno na osobne stereotipe, međugrupne emocije i namjere ponašanja, dok su MSS i BIAS te dio dosadašnjih istraživanja usmjereni na kulturalne stereotipe (Bye i Herrebrøden, 2018; Sadler i sur., 2015; Vaughn i sur., 2017). Nadalje, stereotipi, emocije i namjere mjereni su samo prema jednoj grupi, dok druga istraživanja obično zahvaćaju veći broj društvenih grupa (Bye i Herrebrøden, 2018; Cuddy i sur., 2007; Sadler i sur., 2015; Vaughn i sur., 2017). Ujedno, u ovom smo istraživanju istovremeno provjeravali pretpostavljene odnose obiju dimenzija stereotipa i svih četiriju emocija s dvama tipovima ponašanja $i$ to na razini latentnih varijabli. Za razliku od toga, dosadašnja istraživanja provjeravaju ulogu stereotipa i parova emocija zasebno za pojedine tipove ponašanja i to korištenjem manifesnih varijabli uz koje se veže pogreška mjerenja (Kotzur i 
sur., 2019; Sayans-Jiménez, Cuadrado, Rojas i Barrada, 2017). Neovisno o ovim prednostima, istraživanjem nisu obuhvaćene namjere pasivnih ponašanja, odnosno upitno je koliko namjera nanošenja štete izbjeglicama odražava aktivna, a koliko pasivna ponašanja. Dodatno, ispitivanje je provedeno na online prigodnom uzorku, uz mjeru stereotipa kompetentnosti, bez bitne čestice (pridjev kompetentni). Stoga tek buduća istraživanja, uz istovremenu analizu prediktora svih četiriju tipova ponašanja, mogu cjelovito provjeriti valjanost pretpostavki BIAS-a o ulozi pojedinih dimenzija stereotipa i emocija u objašnjavanju različitih međugrupnih ponašanja. Pritom bi nalaze ovog istraživanja bilo dobro provjeriti i na drugim uzorcima (uz ravnomjerniju raspodjelu po spolu, uključivanje osoba koje se ne služe računalom, odnosno veću zastupljenost starijih osoba) te uz korištenje drugih mjera stereotipa (posebice uz uključivanje pridjeva kompetentni), osjećaja i namjera ponašanja. Ujedno, jedna od mogućnosti za buduća istraživanja je i provjera stereotipa o moralnosti kao zasebne dimenzije stereotipa.

Neovisno o ovim ograničenjima, rezultati rada, uz ranije navedenu teorijsku važnost, imaju i određenu mogućnost primjene u kontekstu mijenjanja stavova i ponašanja prema izbjeglicama. Tako rezultati upućuju na važnost stereotipa o toplini, kao prediktora i pomaganja izbjeglicama i nanošenja štete izbjeglicama. Uz pretpostavku kauzalnih odnosa proizlazi da bi se pokušajima osvješćivanja i/ili mijenjanja stereotipa o toplini izbjeglica moglo utjecati i na ponašanja prema njima. Osim moguće primjene u smislu djelovanja na stavove javnosti općenito, to može biti važno i pri edukaciji pripadnika službi koje izravno rade i kontaktiraju s izbjeglicama te novinara, odnosno autora medijskih priloga o izbjeglicama.

\section{ZAKLJUČCI}

Istraživanjem su na općoj razini potvrđene postavke BIAS-a o primarnosti stereotipa o toplini u odnosu na stereotipe o kompetentnosti za objašnjenje namjera aktivnog pomaganja i nanošenja štete te o emocijama kao neposrednim prediktorima namjera i (djelomičnim) posrednicama efekata stereotipa na namjere. Međutim, nalazi o ulozi pojedinih emocija dijelom odstupaju od očekivanja. Naime, očekivana uloga divljenja i sažaljenja kao važnih prediktora namjera aktivnog pomaganja je potvrđena, ali je utvrđena i uloga odsutnosti sažaljenja i pri objašnjavanju namjere nanošenja štete, a koja se prema modelu nije očekivala. Za prezir je potvrđena očekivana uloga u objašnjenju namjera nanošenja štete, međutim važnost odsutnosti prezira utvrđena je i pri objašnjavanju namjere aktivnog pomaganja iako prema modelu nije bila očekivana. Za zavist nije potvrđen očekivani samostalan doprinos, kao ni medijacijski efekt pri objašnjenju namjera aktivnog nanošenja štete. 


\section{LITERATURA}

Ajduković, D., Čorkalo Biruški, D., Gregurović, M., Matić Bojić, J., Župarić-Iljić, D. (2019) Izazovi integracije izbjeglica u hrvatsko društvo: stavovi građana i pripremljenost lokalnih zajednica. Vlada Republike Hrvatske, Ured za ljudska prava i prava nacionalnih manjina.

Asbrock, F. (2010). Stereotypes of Social Groups in Germany in Terms of Warmth and Competence. Social Psychology, 41(2), 76-81.

Becker, J. C. i Asbrock, F. (2012). What triggers helping versus harming of ambivalent groups? Effects of the relative salience of warmth versus competence. Journal of Experimental Social Psychology, 48(1), 19-27.

Binggeli, S., Krings, F. i Sczesny, S. (2014). Stereotype Content Associated with Immigrant Groups in Switzerland. Swiss Journal of Psychology, 73(3), 123-133.

Brambilla, M. i Leach, C. W. (2014). On the importance of being moral: The distinctive role of morality in social judgment. Social Cognition, 32(4), 397-408.

Brosseau-Liard, P. E. i Savalei, V. (2014). Adjusting incremental fit indices for nonnormality. Multivariate Behavioral Research, 49(5), 460-470.

Bye, H. H. i Herrebrøden, H. (2018). Emotions as mediators of the stereotype-discrimination relationship: A BIAS map replication. Group Processes \& Intergroup Relations, 21(7) 1078-1091.

Bye, H. H., Herrebrøden, H., Hjetland, G. J., Røyset, G. Ø. i Westby, L. L. (2014). Stereotypes of Norwegian social groups. Scandinavian Journal of Psychology, 55(5), 469-476.

Centar za mirovne studije (2017) Istraživački izvještaj - Zastupljenost i indikatori diskriminacijskih i ksenofobičnih stavova u Republici Hrvatskoj u 2017. Zagreb. https://www. cms.hr/system/publication/pdf/98/Zastupljenost_i_indikatori_diskriminac_skih_i_ksenofobi_nih_stavova_u_Republici_Hrvatskoj_u_2017..pdf

Constantin, A. A. i Cuadrado, I. (2020). "We believe, we feel, we act": Testing the BIAS Map predictions during adolescence. Journal of Applied Social Psychology. 50(1), 2-32.

Cuddy, A. J., Fiske, S. T. i Glick, P. (2007). The BIAS map: behaviors from intergroup affect and stereotypes. Journal of Personality and Social Psychology, 92(4), 631-648.

Cuddy, A. J., Fiske, S. T. i Glick, P. (2008). Warmth and competence as universal dimensions of social perception: The stereotype content model and the BIAS map. Advances in Experimental Social Psychology, 40, 61-149.

Eckes, T. (2002). Paternalistic and envious gender stereotypes: Testing predictions from the stereotype content model. Sex Roles, 47(3-4), 99-114.

Fazio, R. H. i Zanna, M. P. (1981). Direct experience and attitude-behavior consistency. U L. Berkowitz (ur.), Advances in Experimental Social Psychology (Vol. 14, str.162-202). New York: Academic Press.

Fiske, S. T. (2015). Intergroup biases: A focus on stereotype content. Current Opinion in Behavioral Sciences, 3, 45-50.

Fiske, S. T., Cuddy, A. J. i Glick, P. (2007). Universal dimensions of social cognition: Warmth and competence. Trends in Cognitive Sciences, 11(2), 77-83.

Fiske S. T., Cuddy, A. J. C., Glick, P., Xu, J. (2002) A model of (often mixed) stereotype content: Competence and warmth respectively follow from the perceived status and competition. Journal of Personality and Social Psychology. 82(6), 878-902. 
Franc, R., Šakić, V. i Kaliterna-Lipovčan, Lj. (2010). Percipirane posljedice doseljavanja i stav prema doseljavanju. Društvena istraživanja, 19(3), 421-440.

Gregurović, M., Kuti, S. i Župarić-Iljić, D. (2016). Stavovi prema migrantskim radnicima i tražiteljima azila u istočnoj Slavoniji: dimenzije, odrednice i razlike. Migracijske $i$ etničke teme, 32(1), 91-122.

Kervyn N., Fiske S. T., Yzerbyt V. (2015). Forecasting the primary dimension of social perception: Symbolic and realistic threats together predict warmth in the Stereotype Content Model. Social Psychology, 46, 36-45.

Kotzur, P. F., Friehs, M. T., Asbrock, F. i van Zalk, M. H. (2019). Stereotype content of refugee subgroups in Germany. European Journal of Social Psychology, 49(7), 1344-1358.

Krajina, I. (2009). Odnos između percepcije ekonomske razvijenosti regija i percepcije kompetencije i topline stanovnika istih regija (Neobjavljeni diplomski rad). Hrvatski studiji -Studij psihologije, Zagreb.

Kuljiš, A. (2009). Stereotipi prema etničkim grupama u Republici Hrvatskoj: provjera postavki modela sadržaja stereotipa (Neobjavljeni diplomski rad). Hrvatski studiji -Studij psihologije, Zagreb.

Leach, C. W., Ellemers, N. i Barreto, M. (2007). Group virtue: the importance of morality (vs. competence and sociability) in the positive evaluation of in-groups. Journal of Personality and Social Psychology, 93(2), 234-249.

Lee, T. L. i Fiske, S. T. (2006). Not an outgroup, not yet an ingroup: Immigrants in the stereotype content model. International Journal of Intercultural Relations, 30(6), 751-768.

López-Rodríguez, L. i Zagefka, H. (2015). The effects of stereotype content on acculturation preferences and prosocial tendencies: The prominent role of morality. International Journal of Intercultural Relations, 45, 36-46.

Matić, J., Löw, A. i Bratko, D. (2019). Personality and ideological bases of anti-immigrant prejudice among Croatian youth. Journal of ethnic and migration studies, 45(13), 23872406.

Pahić, R. (2006). Provjera afektivno kognitivnog modela stava te ispitivanje strukture stereotipa o starim ljudima (Neobjavljeni diplomski rad). Hrvatski studiji - Studij psihologije, Zagreb.

Pereira, C., Vala, J. i Costa-Lopes, R. (2010). From prejudice to discrimination: The legitimizing role of perceived threat in discrimination against immigrants. European Journal of Social Psychology, 40(7), 1231-1250.

Phalet, K. i Poppe, E. (1997). Competence and morality dimensions of national and ethnic stereotypes: A study in six eastern-European countries. European Journal of Social Psychology, 27(6), 703-723.

Rosseel, Y. (2012). lavaan: An R Package for Structural Equation Modeling. Journal of Statistical Software, 48(2), 1-36.

Sadler, M. S., Kaye, K. E. i Vaughn, A. A. (2015). Competence and warmth stereotypes prompt mental illness stigma through emotions. Journal of Applied Social Psychology, 45(11), 602-612.

Sayans-Jiménez, P., Cuadrado, I., Rojas, A. J. i Barrada, J. R. (2017). Extracting the evaluations of stereotypes: Bi-factor model of the stereotype content structure. Frontiers in Psychology, 8, Article 1692. 
Šabić, S. Š. i Borić. S. (2016). At the Gate of Europe: A Report on Refugees on the Western Balkan Route. Zagreb: Friedrich Ebert Stiftung, Regional Office Zagreb for Croatia and Slovenia.

Ufkes, E. G., Otten, S., van der Zee, K. I., Giebels, E. i Dovidio, J. F. (2012). The effect of stereotype content on anger versus contempt in "day-to-day" conflicts. Group Processes \& Intergroup Relations, 15(1), 57-74.

Van Zomeren, M., Postmes, T. i Spears, R. (2008). Toward an integrative social identity model of collective action: A quantitative research synthesis of three sociopsychological perspectives. Psychological Bulletin, 134, 504-535.

Vaughn, A. A., Teeters, S. A., Sadler, M. S. i Cronan, S. B. (2017). Stereotypes, emotions, and behaviors toward lesbians, gay men, bisexual women, and bisexual men. Journal of Homosexuality, 64(13), 1890-1911.

Wojciszke, B. (1997). Parallels between competence-versus morality-related traits and individualistic versus collectivistic values. European Journal of Social Psychology, 27(3), 245-256.

\title{
STEREOTYPES AND EMOTIONS AS PREDICTORS OF BEHAVIOUR TENDENCIES IN THE CONTEXT OF THE REFUGEE CRISIS
}

\begin{abstract}
The aim of the study was to examine the role of stereotypes and intergroup emotions in explaining the stated intentions of intergroup behaviours in the context of the refugee crisis, based on the extended Stereotype Content Model, i.e. the BIAS map model. The data were collected in 2016 through an online survey of a convenience sample of Croatian citizens $(N=468)$ concerning the attitudes towards refugees. The instruments employed in the study captured two dimensions of personal stereotypes towards refugees: warmth and competence, four intergroup emotions: admiration, envy, contempt and pity, and two types of behavioural tendencies towards refugees: active facilitation and active harm. At a general level, the results indicate that stereotypes and intergroup emotions predict intentions of actively helping and actively harming refugees. Specifically, in line with the BIAS model, warmth stereotypes (in relation to competence stereotypes) are confirmed as the primary predictors of both active facilitation and active harm tendencies toward refugees, while emotions are confirmed as important direct predictors of behavioural tendencies, and (partial) mediators of the stereotypes - active behavioural tendencies relationship. However, the results on particular emotions as determinants of active behaviours and mediators of stereotype effects, consistent with some of the findings to date, deviate from theoretical expectations.
\end{abstract}

Key words: stereotypes, intergroup emotions, behavioural tendencies, intergroup relationships, refugees

Primljeno: 16. 12. 2019 

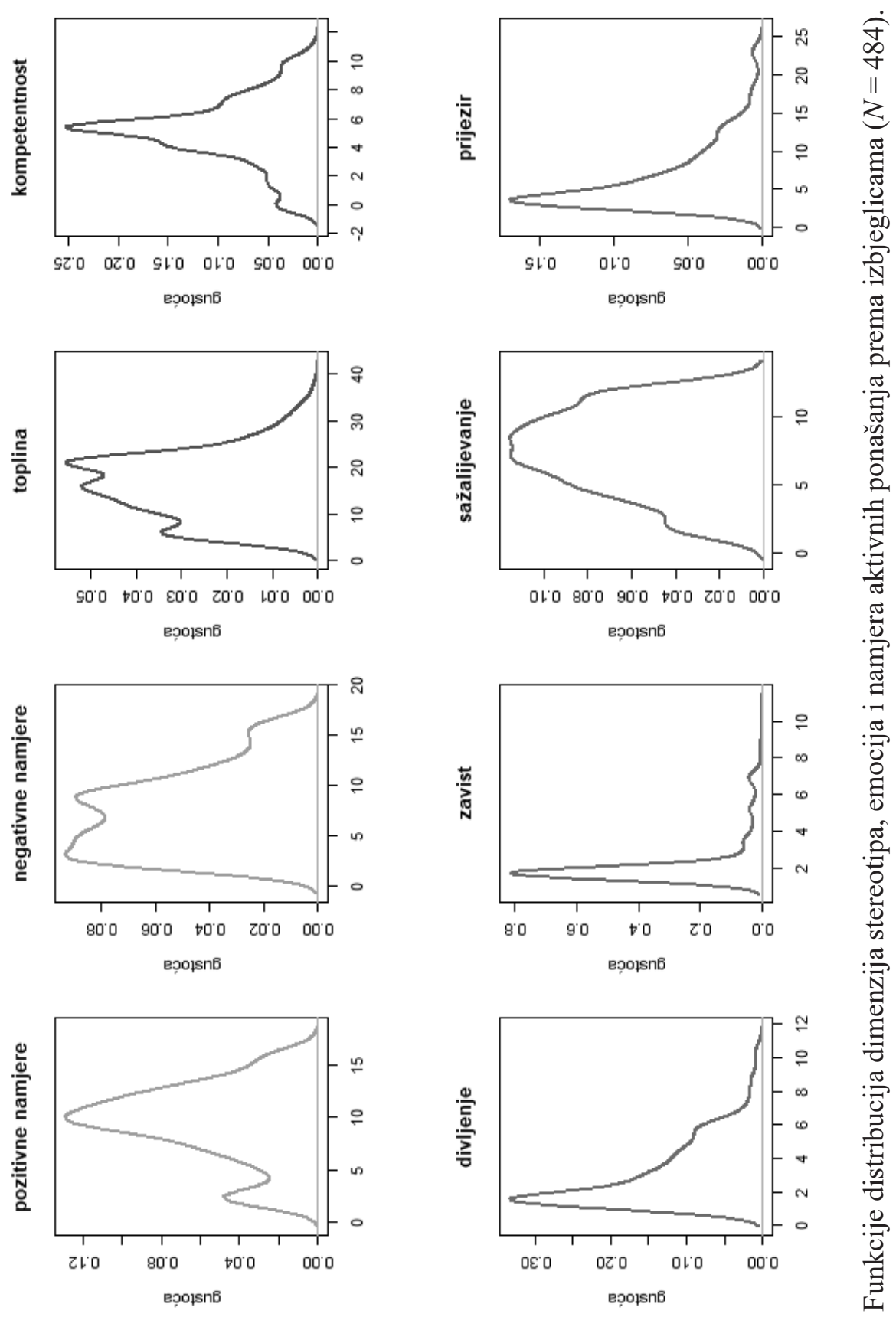